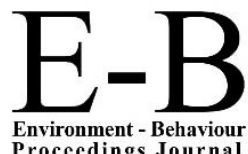

Proceedings Journal
AIVCE-BS-1, 2020ShahAlam

https://www.amerabra.org; https://fspu.uitm.edu.my/cebs; https://www.emasemasresources.com/ AMEABRA International Virtual Conference on Environment-Behaviour Studies, $1^{\text {st }}$ Series cE-Bs, FSPU, Universiti Teknologi MARA, Shah Alam, 24-25 Jun 2020

\title{
The Living House of Pedawa Village: Ordering the domestic life of the dwellers
}

\author{
Ni Ketut Agusintadewi
}

Master of Architecture Programme, Universitas Udayana, Bali, Indonesia

nkadewi@unud.ac.id

Tel: $+62-81236028860$

\begin{abstract}
The paper explores the traditional houses in the village of Pedawa, one of the indigenous settlements in the north of Bali concerning their social-cultural life. A qualitative inquiry with ethnography as the research approach carried out the study. The study reveals that the specific aspects of cultural life, particularly the belief system and worldview, articulate and order the domestic life of the dwellers. Home-making with material culture, evidenced by domestic spaces and spatial arrangement, is designed to give positive cosmic energy to the family.
\end{abstract}

Keywords: domestic life; living house; Pedawa dwellers

eISSN: 2398-4287@ 2020. The Authors. Published for AMER ABRA cE-Bs by e-International Publishing House, Ltd., UK. This is an open access article under the CC BYNC-ND license (http://creativecommons.org/licenses/by-nc-nd/4.0/). Peer-review under responsibility of AMER (Association of Malaysian Environment-Behaviour Researchers), ABRA (Association of Behavioural Researchers on Asians) and CE-Bs (Centre for Environment-Behaviour Studies), Faculty of Architecture, Planning \& Surveying, Universiti Teknologi MARA, Malaysia.

DOI: https://doi.org/10.21834/ebpj.v5i14.2212

\subsection{Introduction}

In the context of home-life, many scholars have argued that the concept of culture can be understood only for the socio-geographical perspective. Subcultures, ethnic groups, and individuals create diversity through ordering their housing; "house life is practised from customs and habits of occupants" (Oliver, 1981). House forms, their internal layouts, and the layout of dwellings in a neighbourhood can be either disruptive or supportive of the culture of their occupants (Wiryomartono, 2014). Lawrence (1985) also wrote that "houses are socio-cultural artefacts".

The concept of culture is both too abstract and too global. It is helpful to explain the relationship between culture and environment (Rapoport, 1998). For this reason, a clear definition of the environment is necessary. In the context of this theme, the environment can be analysed as "a system of settings", as Rapoport's perspective. Altman and Chemers (1985) defined this term as a built environment, which is the result of human alteration of the environment. In terms of the scale of the situation, the house represents a small part.

This paper supports the view that the social system is an expression of culture. The context of 'socio-cultural life' here refers to the products of the Bali Aga culture, particularly home-life in remote dwellings, such as belief systems, values and norms, ideas for housing layout, kinship and family structure. Traditional houses in Pedawa Village, one of the indigenous settlements in the north of Bali, reflect all of the above expressions of culture. In other words, the houses are a reflection of the socio-cultural life that is believed and practised by the dwellers in their daily activities. An essential discussion of why the relatively few things people do in dwellings require so many types and forms of house and settlement develops from Oliver's ideas (2006). The answer to this begins with activity as an expression of lifestyle, values, and finally, culture; thus, addressing the question starts with a discussion of Pedawa dwellers' domestic activities that influence the spatial arrangements within their houses. "Culture helps us to understand the different orders used", as Rapoport (1998) has pointed out.

eISSN: 2398-4287@ 2020. The Authors. Published for AMER ABRA cE-Bs by e-International Publishing House, Ltd., UK. This is an open access article under the CC BYNC-ND license (http://creativecommons.org/licenses/by-nc-nd/4.0/). Peer-review under responsibility of AMER (Association of Malaysian Environment-Behaviour Researchers), ABRA (Association of Behavioural Researchers on Asians) and cE-Bs (Centre for Environment-Behaviour Studies), Faculty of Architecture, Planning \& Surveying, Universiti Teknologi MARA, Malaysia.

DOI: https://doi.org/10.21834/ebpj.v5i14.2212 


\subsection{Purpose of the Study}

The study aimed to explore the home-life of Pedawa dwellers as a reflection of their socio-cultural life. How do the occupants spend their days in their house life? Also, how do they order their housing layout and spatial arrangements that articulate specific aspects of the socio-cultural life of the occupants? These questions could lead to a revelation of an interesting housing phenomenon.

\subsection{Objective of the Study}

The objectives of the study were to identify the daily domestic activities and spatial house layout and to analyse how the Pedawa dwellers order their domestic life in the house, which articulates specific aspects of their socio-cultural life. Their socio-cultural life is dynamic and tends to follow unwritten rules, and the process of transmission inherits across generations.

\subsection{Literature Review}

Through a set of psychological processes, cultures and physical environments link to the people. Altman and Chemers (1985) specify these processes within two ruling classes: mental activities and behavioural activities. The mental activities categorise beliefs and attitudes that affect the physical environment. However, the way people experience their environment motivates them to create shelters. As a result, several cultures view the function of the environment as affecting how people's ideas of living. The next class involves overt behaviours, i.e. how people instigate some actions in response to their environment. Psychological processes inspire cultural similarities and differences between groups of people concerning the environment.

Relationship between culture and environment consists of five integrated and interdependent elements and additional sub-elements to understand such a relationship. One of those elements is Environmental Orientations and Worldviews with four additional subelements, namely cosmology, religion, values, and norm. Each component influences the others in complex ways and contributes to a social system. Environmental orientations and worldviews remind us to be aware of how people arrange their housing layout and the use of space in their homes, and how to maintain this tradition over generations. These are particularly relevant to the topic of this study.

Rapoport (in Kent, 1990) points out that activities are direct expressions of lifestyle and ultimately of culture. Culture also mediates the specifics of the event in the house. That is to say, they involve the particulars of activity systems, in what order or sequence they occur, the nature of these sequences, how they are linked or separated, who is involved, where and when they occur, and other interconnected variables. In the context of this study, space inevitably organises activity systems.

\subsection{Methodology}

\subsection{Study Area}

Pedawa Village is located in a remote area within the range of northern mountains of Bali, precisely in Buleleng Regency. As an ordinary indigenous village of Bali (known as the Bali Aga), the spatial pattern of the settlement follows a cardinal orientation, namely from the highest hierarchy (hulu or the mountain) in the south to the lowest one (teben or the sea) in the north.
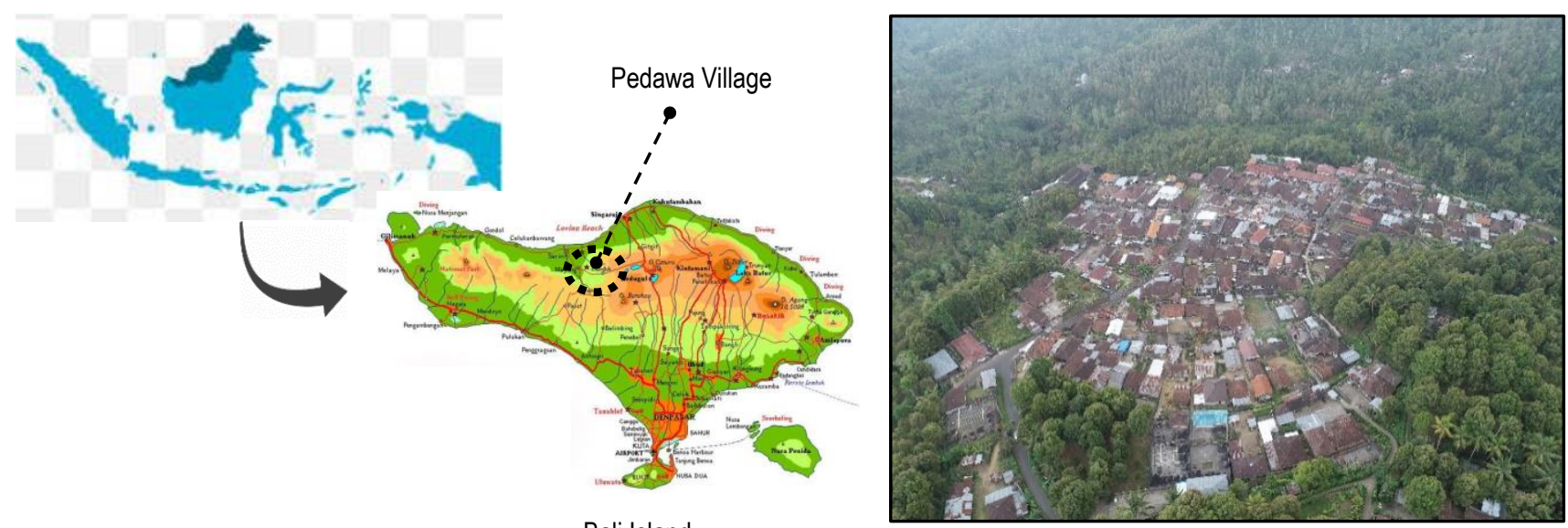

Bali Island

Fig. 1. A pnotograpn ot the study area from the bird-view perspective

(Source: Local government's documentation of Pedawa Village, 2019)

\subsection{Going to the Field}

A qualitative inquiry accomplished the study. This method is a research strategy that underlines connections and uses words rather than numbers in collecting and analysing data (Bryman, 2012).

Fieldworks started a pre-observation to give a preliminary picture of the real situation. The first step was walking around the Pedawa houses to provide us with a sense of place and the chance to become familiar with the context. The second step was selecting the homes for inclusion as appropriate cases. The essential selection criterion was that samples should show a strong presence of dynamic 
domestic life and the originality of the house layout. Importantly, the dwellers should also voluntarily give themselves to be respondents and allow us to access their house. It required the identification of physical, behavioural, and spatial settings. Purposive sampling selected the cases as representative samples. At this stage, it was possible to identify eight dwellings that were feasible and accessible to observe and potentially contained rich information. Interviews, physical observation, rough sketches, and photographs collected the data.

Table 1. Themes and variables within the field survey approach

\begin{tabular}{lll}
\hline Themes & Variables & Fieldwork Activities \\
\hline Domestic life & Religious activities (daily rituals and praying for festivities) & Interviews, physical \\
& $\begin{array}{l}\text { Daily activities (cooking and eating, sleeping arrangements, social } \\
\text { interactions and leisure) }\end{array}$ & mapping, \\
observation, \\
Spatial order & $\begin{array}{l}\text { Hierarchy of spaces and orientation (hierarchy of ordered space, } \\
\text { cardinal orientations, the influence of the sacredness of directions }\end{array}$ & photographic records \\
& $\begin{array}{l}\text { on the sleeping position, existence of hierarchy spaces) } \\
\text { Sacred and profane spaces (spatial layout) }\end{array}$ & \\
\hline & (Source: Formulated from the theoretical framework, 2020)
\end{tabular}

\subsection{Analysis and Interpretation of Data}

This ethnographic research focuses on the entire Pedawa Village houses as a cultural group. This strategy describes and interprets the shared and learned patterns of values, behaviours, and beliefs of a culture-sharing group (Creswell, 2007). Linkages, insights and connections analysed from the field data and associated with the purpose and objectives of the study. Then, it was possible to answer how questions satisfactorily. As for the structural analysis, this study uses a socio-cultural dimension to identify a link between people, houses, and socio-cultural factors within the process of inhabiting.

\subsection{Research Limitations}

The study associates with several limitations: First, it only explored a set phenomenon of house life in Pedawa Village, in particular the spatial arrangements in the house that represents the belief system of the dwellers. Therefore, the result of the study is not sufficiently relevant to other Bali Aga villages. Second, the study investigated limited cases with a few modified house layouts. At the same time, in research sites, it should explore many types of house layouts to develop the rich of appropriate information.

\subsection{Findings}

\subsection{Daily Domestic Activities}

Six necessary domestic activities - sleeping, eating, cooking, washing, bathing, and storing - are common to all cultures (Agusintadewi, 2015). Nevertheless, the increase in these activities is primarily related to the ideas and values of dwellers in their specific context. Those domestic activities and their spaces eventually become culturally variable.

According to their housing layout, Pedawa families hold their occasional ceremonies in natah (the inner house yard), bandung rangki (an enclosed pavilion), and sanggah (the family shrine). The families also have another type of shrine: sanggah kemulan nganten. Young married sons have to build this shrine in the house of origin of one extended family.

The Pedawa families practice two ritual activities: praying on holidays and daily praying. They prepare offerings of flowers daily, and only a small effort is needed to assemble and present these around the house. The families also offer all kinds of offerings in many places in thanks to God and the ancestors. Unlike in the daily praying, preparing and arranging offerings on the festivals use much space. The families make offerings in an enclosed pavilion, the bandung rangki or bale-bale (a platform) in jineng (the granary).

\subsection{House Layout}

The spatial pattern of Pedawa Village follows the family structure that includes a kinship system or dadia. The village has 37 dadia that consist of several banjarans in many variants of layouts and dwell in some families (Widiastuti, 2020). Each family unit initially had three function spaces: sanggah kemulan nganten (outdoor shrine), bandung rangki (enclosed pavilion), and jineng (granary). However, Pedawa families now commonly have no granary in their house yard because they demolished this building. Nowadays, the upper level of the jineng, where agricultural produce used to be stored, is only a space and is never filled with paddy or rice. However, the upper store reflects past glories, in which the jineng expressed the social status and prosperity of the owner. The size of this building can still indicate how prosperous the owner is. Temporarily, sanggah kemulan nganten is made of constructed bamboo strips and placed in the house yard. Young married sons build this holy construction to worship betara-betari (the ancestors). Figure 2 illustrates three variants of the house layout of a banjaran.

Interestingly, the mirror system of bandung rangki implements the kaajekan concept (the spatial configuration) in the house layout of a banjaran. Several spatial configurations have some adjustments in terms of their location as their similar features. The kaajekan reflects a harmonious relationship between humans and nature. As a result, the bandung rangki locates next to one another. Everything in the enclosed pavilion will be mirrored onto the same building that is occupied by another family. However, the spatial pattern of the buildings and orientation of the banjarans remain unchanged, as illustrated in Figure 3. 


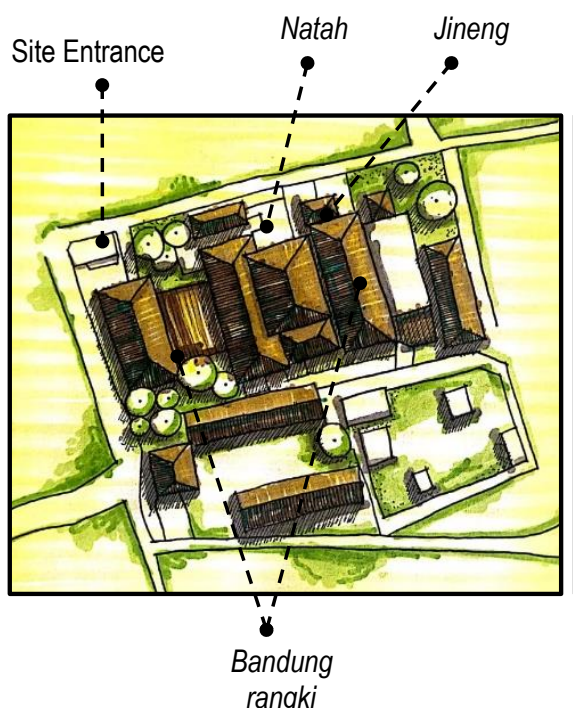

(a)

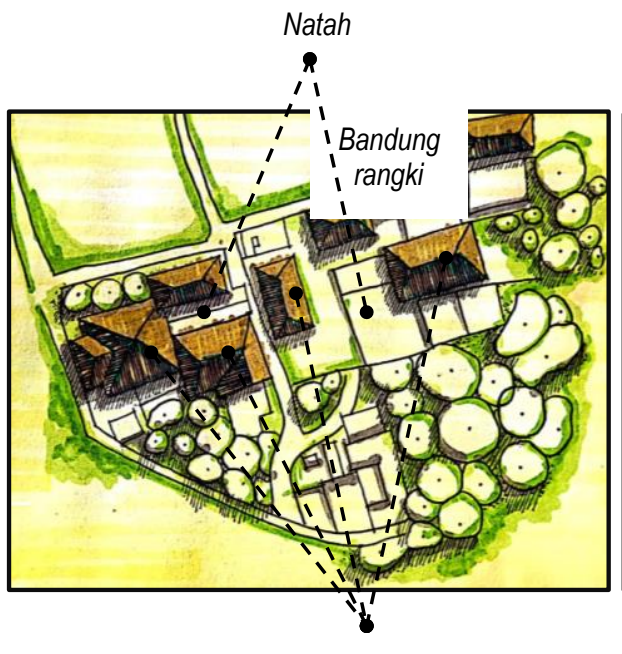

(b)

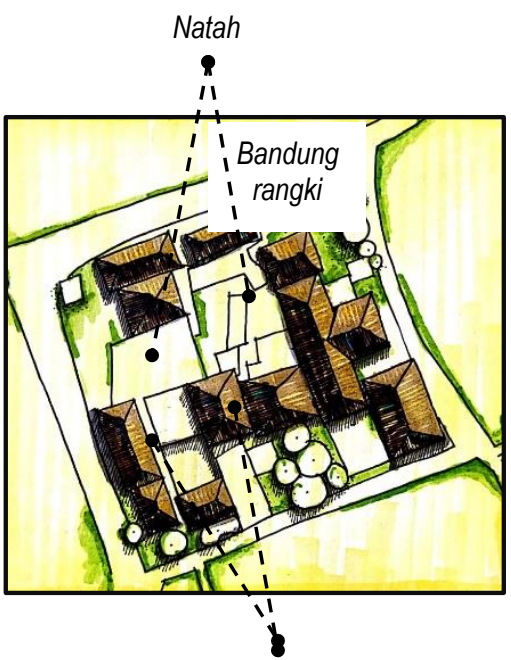

(c)

Fig. 2. (a) Traditional house layout; ( $b$ and $c$ ) Modified house layout (Source: Roughly sketched on sites by Widiastuti, redrawn by Prathiviningsih, April 2020)

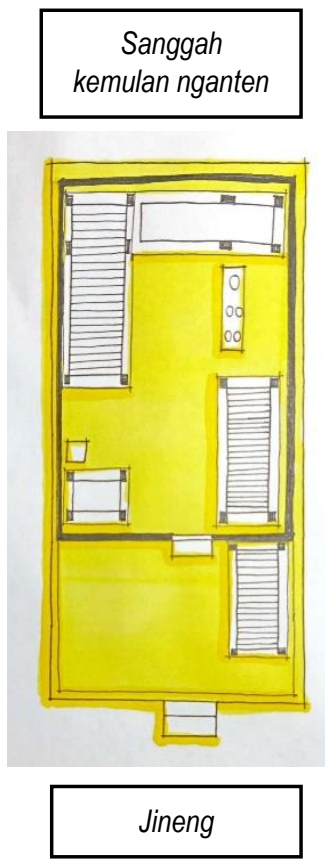

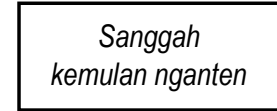
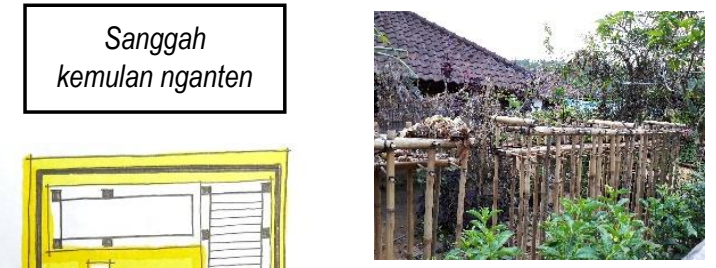

Sanggah kemulan

nganten

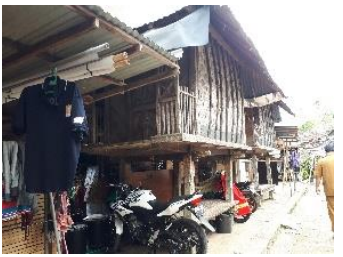

Bandung rangki
Jineng

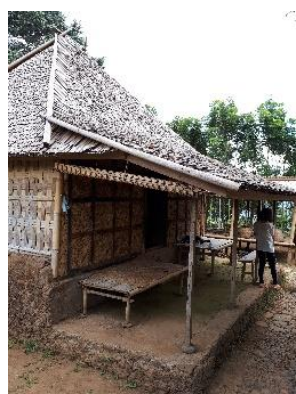

Imaginary line

Fig. 3. The mirror system of bandung rangki that reflects the kaajekan concept (Source: Rough sketches on site, redrawn by Prathiviningsih, April 2020)

\subsection{Bandung Rangki: the Sacred-Profane Pavilion}

The enclosed pavilion in a Pedawa house functions to accommodate domestic life, both ritual and home activities. As a sacred and profane space in the house, the dwellers use bandung rangki for doing five necessary domestic activities: sleeping, eating, cooking, washing the dishes, and storing. Nevertheless, additional facilities in the house to support the various activities held there. It is mostly related to the ideas and values of dwellers in a specific context and time.

Bandung rangki has a specific spatial arrangement: pawon jakan (the kitchen), jeding (a water container), and sedahan (a palace for the Gods). Pawon jakan is in hulu (the mountain orientation), while jeding is in teben (the sea orientation). Both hulu and teben are cardinal orientations for the dwellers. The dwellers believe that the hulu is a sacred area and has the highest hierarchy in the house layout, and the teben is the most profane that has the lowest position in the cardinal orientation. In the indoor setting, the occupants also believe that the pawon jakan and jeding are places where the Gods reside, as sedahan is. Sedahan symbolises a palace for Ida Betara Brahma and Ida Betara Wisnu (the goddess). 
In the process of inhabiting, the concept of space hierarchy describes home-making with material culture, both indoor and outdoor. The front part or teben (the bottom) and the back part or luan (the top) are two parts on different spatial levels. Pedeman gede (a master bed for parents) is at the backside, at the same level as pawon jakan. At the front, a pedeman kicak (a small bed for children) has the same level as jeding. Both levels reflect a symbol of the Segara Giri concept. Pawon jakan has the higher space that represents fire in the mountain.

Meanwhile, pedeman kicak is a representation of the paternalistic system of the village (the concept of luan-teben). This concept ultimately affects the levels of the rooms in this enclosed pavilion. Therefore, parents occupy the higher-level space (Iuan), while children occupy the lower level space. Here is the soul of the building that is believed and practised by the dwellers over the ages. The building also conducts one part of a funeral festivity. The corpse laid down on the pedeman gede and water from the jeding cleans the body. The occupants make a temporary floor drain, and it will be filled back after the ceremony. The 'dirtiness' can be destroyed by fire from a traditional stove in the kitchen (bungut paon). Bandung rangki can be said as 'the sacred-profane pavilion' because the building accommodates both ritual and daily activities. The spatial arrangement in the pavilion reflects their belief system.

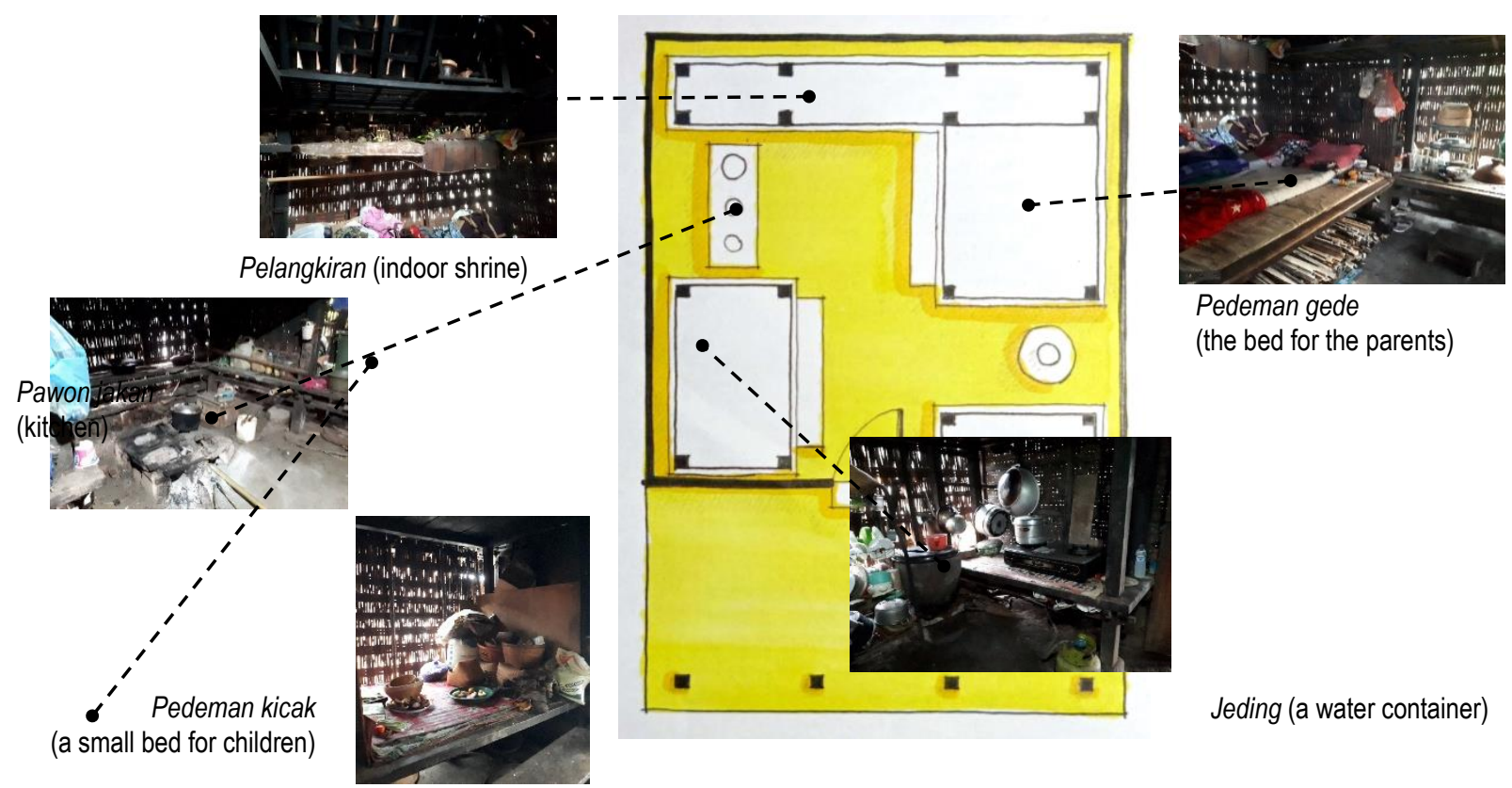

Fig. 4. The spatial arrangement of Bandung Rangki

(Source: Rough sketches on site, redrawn by Prathiviningsih, April 2020)

\subsection{Discussions}

\subsection{Domestic Life: A Setting of Activity}

Rapoport (in Kent, 1990) highlights that activities are direct expressions of lifestyle and ultimately of culture. Culture mediates the specifics of activity in the house. Therefore, home and domestic life cannot be looked upon as a single activity, but it must consider as activity systems. It explains how continuing socio-cultural processes modify behavioural settings, as well as how they shape and change housing layouts. It describes the domestic activities carried out in Pedawa houses.

The Balinese interprets a house as a cultural entity, apart from being a shelter. Interestingly, the Bali Aga families also have the same perspective as the Balinese on how to understand the term house. Cases on the research site defined the term house from the perspective of the Pedawa dwellers. In this discussion, the occupants also interpret a home as a cultural entity, apart from being a shelter. A home can be a directory of essential events from the past, a repository of ancestral objects, a ritual attractor, and the centre of family activities. From the cases studied here, two types of activities: ritual and daily, define domestic activities in Pedawa houses. All events are bringing together in context and time; a house can accommodate how the dwellers spend their days. A system of activities of the dwellers practises in the house.

The dividing line between the sacred and profane worlds occurs in a house. It fully supports Eliade (in Agusintadewi, 2015) viewpoint: "the house, like a temple and city, becomes a symbol of the universe with God at its centre and in charge of creation". He also highlights that "the threshold of the house is regarded as one of the most important dividing lines between the inner private space and the outer public world". A description of Pedawa houses reveals much of what Eliade has presented. Their cosmological perspective, particularly the belief to the ancestors on their lives on earth, appears in the cultural space of the house. The Bali Aga families believe that life is sacred and a ritual sanctifies each stage of life. A series of ceremonies around the life cycle starts from the period of pregnancy and ends with death (Waterson, 1997). 
Ultimately, as a setting of activity, domestic life in Pedawa houses has identified that the nature of the link between culture and the domestic built environment, in this case, the house, tends to assume that both are equivalent units implicitly. In other words, they are equal in scale. It is relevant to Rapoport' (in Kent, 1990) viewpoints. However, culture is essentially a vast domain, whereas the house is a small part of and a subset of culture.

\subsection{Domestic and Ritual Spheres: Two in One}

Waterson (1997) emphasises that "for the anthropologist, the study of inhabited space, its construction and daily use, can provide a way into a whole culture and its ideas." For this reason, inhabited spaces reflect the cultural values of the occupants. Houses from all cultures can have symbolic dimensions and carry specific messages. This meaning is inherent in people, not in things. It is due to people wanting to capture particular essence in their environment. Waterson (1997) also argues that "ancestors share with deities a position of prime importance in indigenous religions in South-East Asia...". Therefore, why the Pedawa dwellers respect their ancestors and make enormous efforts to maintain a spiritual relationship with their house of origin as a palace of their ancestors is an essential meaning.

Domestic life in the houses in Pedawa Village reveals that a house is more than a physical space in which people live; it is also space where social interactions and rituals take place, how the use of space represents the house itself. Several sociological and historical studies of housing have claimed that the layout of a house expresses underlying cultural values and norms, and choices for the use of space (Ozaki, 2002). Indeed, Pedawa Village' homes reflect the above perspectives.

\subsection{Conclusions and Recommendations}

The Pedawa dwellers believe that the length of life is a sacred time. Their houses symbolise the universe with the Creator at its centre. Dedication to God and the ancestors cause the dwellers to practice religious activities, both in daily prayers and occasional festivities. Their generations continually preserve these activities. The belief system and worldview of the occupants play an essential role in the way that they order cultural settings and apply them in their houses, particularly in terms of determining the hierarchy and the sacredness of domestic spaces in the house layout.

A range of evidence in research sites shows that in the process of inhabiting the occupants attempt to develop the house beyond basic functional necessities. Home-making with material culture, evidenced by religious symbols and spatial arrangement, aims to express the value of the occupants' belief and social system, also creates positive cosmic energy to the family.

Ultimately, the cultural values within the domestic life of the Pedawa dwellers should be maintained and preserved. The Pedawa Village is not only a cultural heritage or a living museum for the next generations, but the village can also continually accommodate cultural transformation and adjust itself to globalisation and modernisation. Cultural transformation threats to the existence of traditional settlements in a rural area (Harun, 2018). The core elements of cultural values should be investigated and identified for a set of local identity that can be preserved in social sustainability, as Jaffar (2019) suggested. It means that the identification of the core elements of the village defines a preservation method. Besides that, we can explore the building structure and the environment in the village. Approaches to environmental sustainability and climate adaptation could be an exciting topic through the analysis of traditional houses (Nguyen, 2018). Those are valuable opportunities for future researches.

\section{Acknowledgements}

I would like to dedicate this paper to the dwellers of Pedawa Village. Special thanks to the leader of the local authority who has allowed me to go to the ground. Thanks to all the respondents for accessing me to observe their houses and their time for interviews. Finally, thanks to my undergraduate student, Ni Luh Made Rai Dyah Prathiviningsih, for helping me with redrawing the rough sketches made at the research sites.

\section{References}

Agusintadewi, N.K. (2015). Transforming Domestic Architecture: a Spatio-temporal Analysis of Urban Dwellers in Bali, PhD. Thesis. Newcastle upon Tyne, United Kingdom: Newcastle University

Altman, I. \& Chemers, M.M. (1985). 'Cultural Aspects of Environmental-Behaviour Relationships.' in H. C. Triandis \& R.W. Brislin (Eds.). Handbook of Cross-cultural Psychology. Vol. 5. Boston: Allyn \& Bacon. Pp. 55-85.

Bryman, A. (2012). Social Research Methods. Fourth Edition. Oxford, New York: Oxford University Press.

Creswell, J.W. (2007). Qualitative Inquiry \& Research Design: Choosing among five approaches. Second Edition. California: Sage Publication Inc.

Harun, N. Z., \& Jaffar, N. (2018). Enhancement for Rural Liveability: Changes and impacts on the traditional Malay settlement. Environment-Behaviour Proceedings Journal, 3(9), 127-134. https://doi.org/10.21834/e-bpj.v3i9.1544

Jaffar, N., Harun, N.Z., Mansor, M. (2019). The Key Determinant Factors for Social Sustainability in Traditional Settlement. Environment-Behaviour Proceedings Journal, 4(12), 43-52. https://doi.org/10.21834/e-bpj.v4i12.1944 
Kent, S. (1990). 'Activity Areas and Architecture: An Interdisciplinary view of the Relationship between the Use of Space and Domestic Built Environments', in Kent, S. (ed.) Domestic Architecture and the Use of Space: An Interdisciplinary Cross-cultural Study. Cambridge: Cambridge University Press, pp. 1-8.

Lawrence, R.J. (1985). 'Domestic Space and Society: A Cross-cultural Study', Comparative Studies in Society and History, 24(1), pp. 104-130.

Nguyen, H. M. (2018). Lessons Learned from Traditional Vietnam Northern Lowland Habitation. Asian Journal of Environment-Behaviour Studies, 3(9), 57-64. https://doi.org/10.21834/aje-bs.v3i9.299

Oliver, P. (2006). Built to Meet Needs: Cultural Issues in Vernacular Architecture. London: Architectural Press.

Ozaki, R. (2002). 'Housing as a Reflection of Culture: Privatized living and privacy in England and Japan', Housing Studies, 17(2), pp. $209-227$.

Rapoport, A. (1990). "Systems of Activities and Systems of Settings", in Kent, S. (ed.) Domestic Architecture and the Use of Space: An Interdisciplinary Cross-cultural Study. Cambridge: Cambridge University Press, pp. 9-20

Rapoport, A. (1998). 'Using "Culture" in Housing Design', Housing and Society, 25(1\&2), pp. 1-20.

Waterson, R. (1997). The Living House: An Anthropology of Architecture in South-East Asia. New York: Watson-Guptill Publications.

Widiastuti, Patutusi, S.A. (2020). "Spatial Composition Model of Banjaran in Pedawa Housing, Buleleng, Bali" in Satria, M.W, et.al. (ed) Pedawa Village Exploring the Indigenous Settlement in Buleleng. Revised Edition. Denpasar: Satria Aksara, pp. 121-131.

Wiryomartono, B. (2014). Perspectives on Traditional Settlements and Communities: Home, Form, and Culture in Indonesia. Singapore: Springer. 